\title{
都立病院における施設への投資金額の推移と改築・改修工事費の特徵の分析 TRANSITION OF THE INVESTMENT AMOUNT OF MONEY TO AN INSTITUTION AND
ANALYSIS OF THE FEATURE OF RECONSTRUCTION AND
REPAIR WORK EXPENSE IN A METROPOLITAN HOSPITAL
}

山本康友*, 吉田倬郎**, 山下光博***

Yasutomo YAMAMOTO, Takurou YOSHIDA and Mitsuhiro YAMASHITA

\begin{abstract}
As medical technology has made rapid progress, there is a great demand for medical facilities that can provide the medical services corresponding to the progress. The purpose of my research is to have a clear grasp of the present situation of medical facilities and their building maintenance. I studied the transition of the investment in the metropolitan hospitals. The number of hospitals in Japan has decreased by $10 \%$ within 15 years, whereas the number of hospitals that have recuperation beds has been increasing.

Tokyo metropolitan government has increased the investment in plant and equipment of hospitals. My study showed that there was an average interval of 3.72 years between initial construction and reconstruction of hospital site ("campus type"), and 7.11 years in case there was a single building at the site. It turned out that there was an average interval of 27.4 years between initial construction and reconstruction of medical institutions (including an interval between two reconstructions.)
\end{abstract}

Keywords: Metropolitan hospital, Investment, Campus -type, Single building, Reconstruction 都立病院、投資、キャンパス型、単独棟型、改築

\section{1. 研究の背景と目的}

著しい少子・高㱓社会が進展していることは、厚生学働省の統計 ${ }^{1)}$ における「合計特殊出生率が 1.25 (2005 年確定値)」「100 歳以上の 高齢者が 25,554 人 (2005 年修正值) 、「平均寿命が女性 85.49 歳、男 性 78.53 歳（2005 年確定值）からも明らかである。また、伝染病、 特に結核の発生減少などによる疾病構造の変化、治療・検査機器の開 発に伴っての医療機器技術の目覚しい進歩や患者の権利意識の高ま りに伴って、症状に忘じたきめ細やかな医療サービスなどが求められ てきている。まさに、医療改革という時代の流れとともに、医療体制 が大きく変化している。

こうした背景の中で、医療施設に関しては、1992 年の第 2 次医療法 改正から始まって 2000 年の第 4 次医療法改正まで、特定機能病院 療養型病床群の指定や、病床区分の見直しといった様々な形で病院の 機能分化に関わる法改正が行われてきている。

このため、既存の病院についても、従来から行われている改修需要 等に加えて、特定の治療行為に特化した機能への対応など、さらなる 設備改修・更新、増築への対応が迫られている。

このことから、医療を支え続ける施設環境の更新や改修が、常に求 められてきている。そのため、ストックとしての医療施設を、適切に
維持し活用することが、今後一層重要になるものと考えられる。

本研究では、以上の考察を踏まえて、現在の医療建筑ストックの状 況を把握するとともに、医療建築ストックにお汀る維持保全業務の赛 態の一面を明らかにし、それを基に今後の課題を示すことを目的とし ている。

\section{2. 研究方法}

本研究における研究方法は以下のとおりである。

(1) 医療施設調查 ${ }^{2)}$ や建築動態調查 ${ }^{3)}$ を参考に、医療施設建築のス卜 ックの状況を把握する。

(2)投資金額の分析データは、昭和 29 年から平成 15 年までの改修、 改築、補修工事などについて記録として残されている東京都財務局建 築保全部発行の営縓年報のうち「局別工事施工一覧」の衛生局分から 抜粋している。

このうち、東京都病院経営本部が、平成 18 年度現在で所管してい る 11 病院と(財)東京都保健医療公社所管の 2 病院 ${ }^{4)}$ を対象にして、工 事内容、工事頻度、工事費用などの都立病院における投資金額の割合 と推移、そして、改勧及び改修における工事周期について、分析を行 っている。
* 東京都港区

** 工学院大学大学院 教授.工博

*** 工学院大学 大学院生
Minato City Hall

Prof., Dept. of Architecture, Kogakuin Univ., Dr. Eng. Graduate Student, Kogakuin Univ. 
表 1 分析対象病院の概要

\begin{tabular}{|c|c|c|c|c|}
\hline 病院名 & 病床数 & 正床面積 & 薄整地面積 & 多来 $(\mathrm{A} / \mathrm{\theta})$ \\
\hline 松沢病院 & 1,258 & 59,658 & 192,558 & 370 \\
\hline 駒込病院 & 801 & 65,146 & 34,725 & 1,280 \\
\hline 府中病院 & 761 & 66,774 & 174,313 & 1,675 \\
\hline 墨東病院 & 729 & 72,736 & 19,987 & 1,500 \\
\hline 荏原病院 & 500 & 57,036 & 40,061 & 1,010 \\
\hline 広尾病院 & 500 & 40,090 & 22,172 & 925 \\
\hline 大㙫病院 & 500 & 45,692 & 18,702 & 1,020 \\
\hline 豊島病院 & 360 & 49,799 & 25,015 & 640 \\
\hline 大久保病院 & 300 & 23,305 & 10,185 & 640 \\
\hline 神経病院 & 296 & 23,991 & 174,313 & 30 \\
\hline 清瀬小児病院 & 255 & 22,513 & 48,454 & 295 \\
\hline 梅ヶ丘病院 & 242 & 16,831 & 24,963 & 140 \\
\hline 八王子小览病院 & 90 & 7,182 & 3,763 & 150 \\
\hline
\end{tabular}

\section{3. 医療施設の現状}

\section{1 病院数 $\cdot$ 病床数}

厚生労働省の医療施設調查によると、全国の病院数は、図 1 に示す ように、平成 2 年の 10,096 病院をピークとして減少傾向に転じ、平 成 16 年 10 月には、 9,077 病院までになっている。

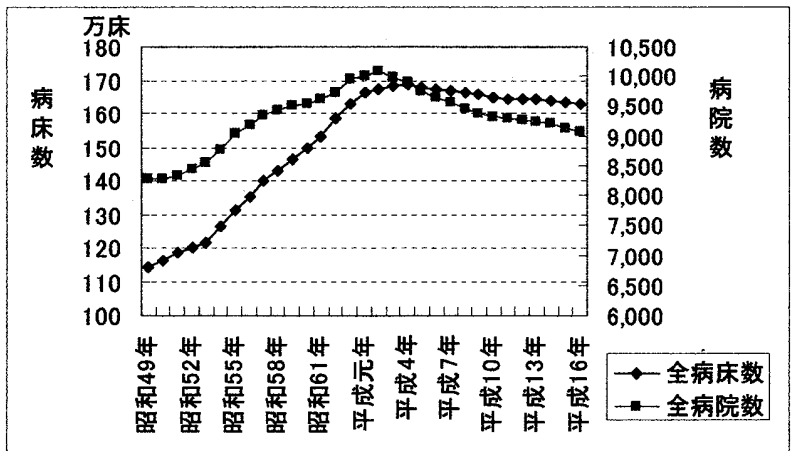

图 1 病院数・病床数の推移

病床数も同様の傾向を示していて、平成 4 年の $1,686,696$ 床をピー クとして減少に転じ、平成 16 年には $1,631,553$ 床となっている。平 成 4 年の病床数を 100 とすると平成 16 年の病床数は 96.7 となり、病 院数の減少割合に比べて病床数の減少割合は明らかに小さい。

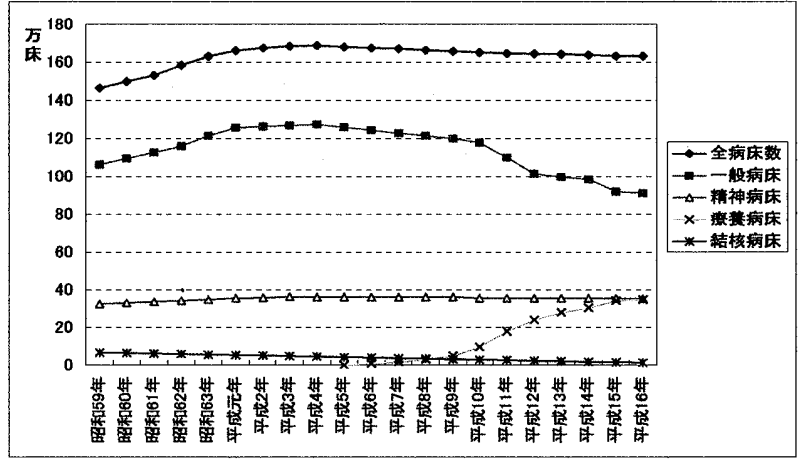

図 2 病床の種類別にみた病院病床数の年次推移

\section{2 病院の延べ床面積の増加}

近年は、医療分野でも、「患者へのサービスの向上」や「病床環境 のアメニティの確保」などに代表されるように、入院患者の療養環境
の向上の必要性が強く求められるようになってきている。

全国の病院の全延べ床面積と 1 床当たりの面積の推移を図 3 に示し たが、昭和 62 年には、 $36.4 \mathrm{~m}^{2} / 1$ 床であったものが、着実に増加して、 平成 14 年には $45.9 \mathrm{~m}^{2} / 1$ 床となり、 15 年間で約 $25 \%$ の増加となって いる。なお、 1 床当りの床面積は、各年の延べ床面積を各年の病床数 で割ったものとして求めている。

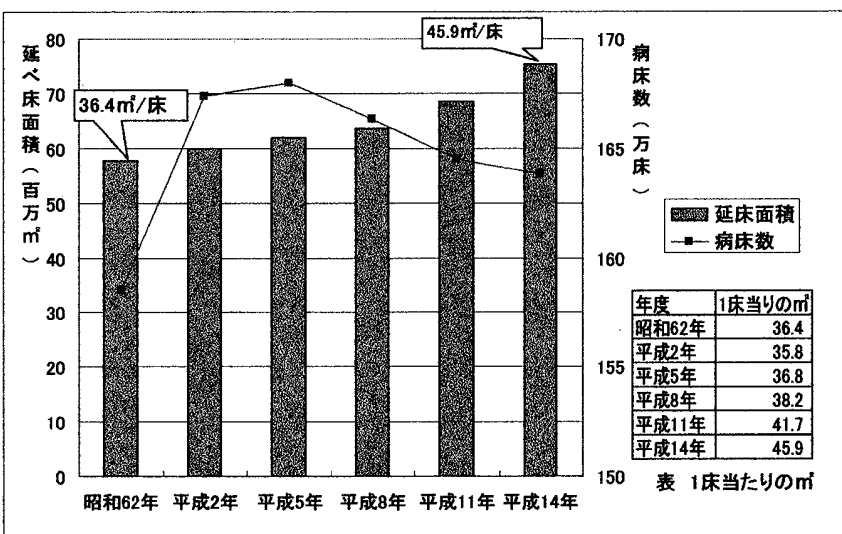

図 3 病院延べ床面積と 1 床当たりの面積の推移

これらは、病室面積の桩大、一部の病棟における定員設定、車椅子 で相互に交差できるようにするための廊下幅の搪大、見舞い客のため の食堂や患者相互、見舞い客と患者との談話室の設置などによるもの と考えられる。そして、その結果として、病院全体の延べ床面積が短 期間のうちに急激に扗大寸ることとなった。

\section{3 医療施設の工事概要}

国土交通省が実施している建築動態統計調査の建築物着工統計で は、建物の使途別集計として、病院・診療所の数值が公表されている。 図 4 のように、建築物の着工数について過去 30 年間の傾向をみると、 全建築物は少しずつ堿少の傾向を示しているのに対して、病院・診療 所は平成 2 年以降も増加傾向にある。このことから、バブル時期以降 にも、医療施設の高い需要があることが確認できる。

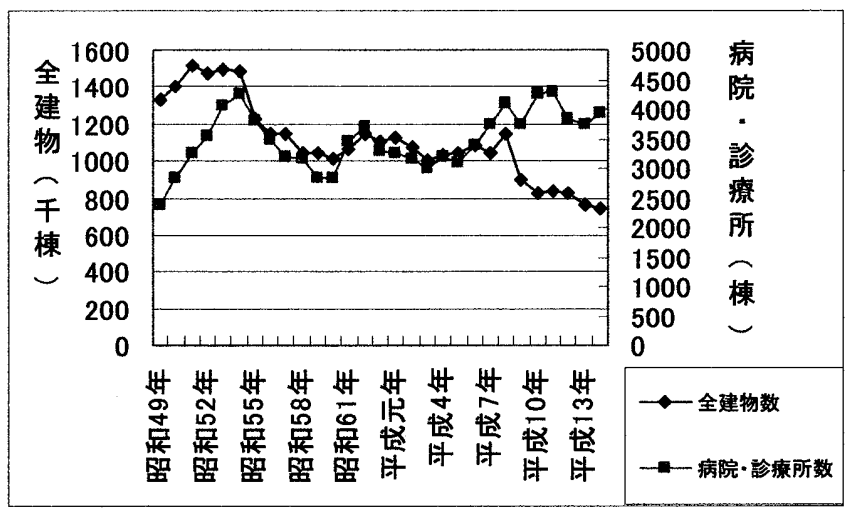

図 4 建築物数の推移 （全建物、病院・診療所）

また、工事予定面積をみても、全建築物の場合、昭和 63 年辺りか ら減少傾向であるが、病院・診療所は着工数が増加していることもあ って、平成 2 年以降に増加傾向に転じ、平成 10 年にピークを迎えて いる。 


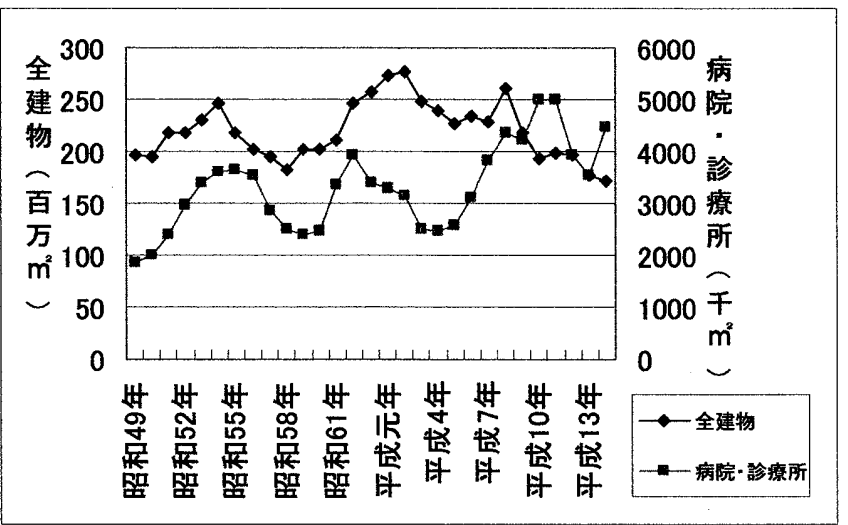

図 5 工事予定面積の推移(全建物、病院・診療所)

図 6 から、病院・診療所の工事費予定額は、概ね上昇傾向を続けて きているといえる。全建物の工事費予定額が、バブル時期を境に減少 に転じているのに比べ、病院・診療所の工事費予定額は、バブル時期 と同じか、それ以上の金額になっている。

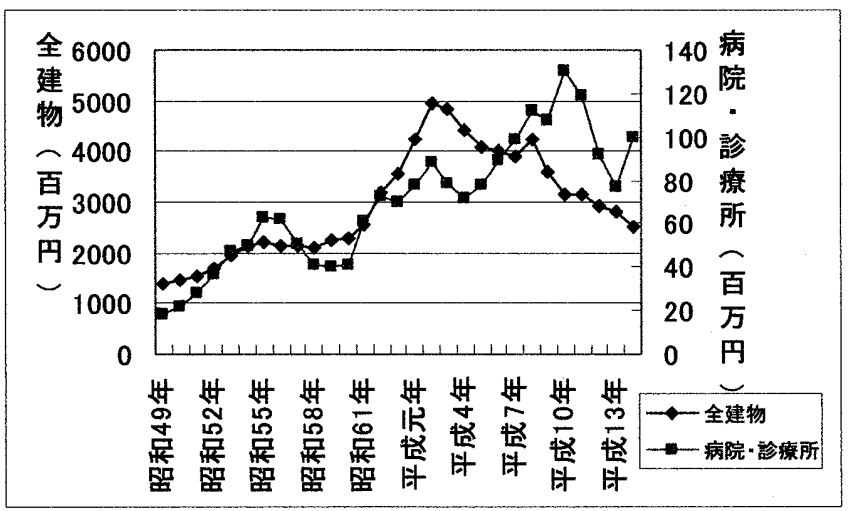

図 6 工事費予定額の推移 (全建物、病院・診療所)

病院数は減少しているが、病床数はそれほど減少していないうえに、 1 床当たりの床面積は増加していることがわかる。

このことから医療施設ストックの延べ床面積は、ますます増加する 傾向が見られ、投資金額についても、施設の種類にもよるが、全体と して現状維持か、あるい増加が予想される中で、新筑及びストック 対応一の医療施設の投資というものが、金額的にも内容的にも非常に 重要であることがわかる。

しかしながら、その具体的な様子を示す適切な資料については、現 時点では公にされていない。こうした状況を踏まえ、本研究は、今後 の医療施設の投資計画に活用できる知見を得るべく、東京都の医療施 設について、投資状況の詳細な資料を分析したものであり、その成果 を以下に示す。

\section{4. 都立病院への投資金額の推移}

\section{1 工事種別金額の構成割合}

図 7 および図 8 は、15 病院について昭和 29 年から平成 15 年度まで の総投資金額を工事種別に示したものである。このうち都立 13 病院 は、以降の分析対象であり、後は、現在は廃止されている 2 病院（台 東病院・築地産院）である。

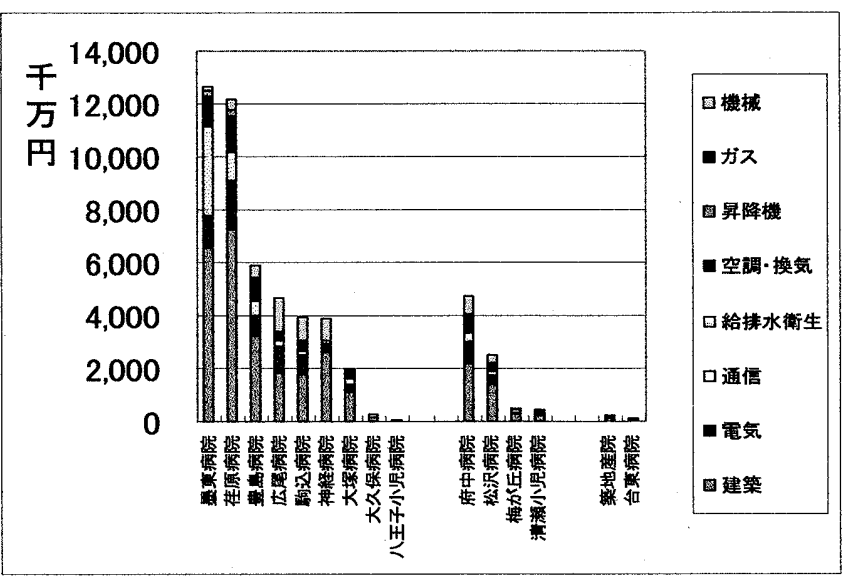

図 7 病院全体の総工事金額の工種別構成金額

また、図 8 は、各々の病院の投資金額に対する各種工事の割合を示 したものである。

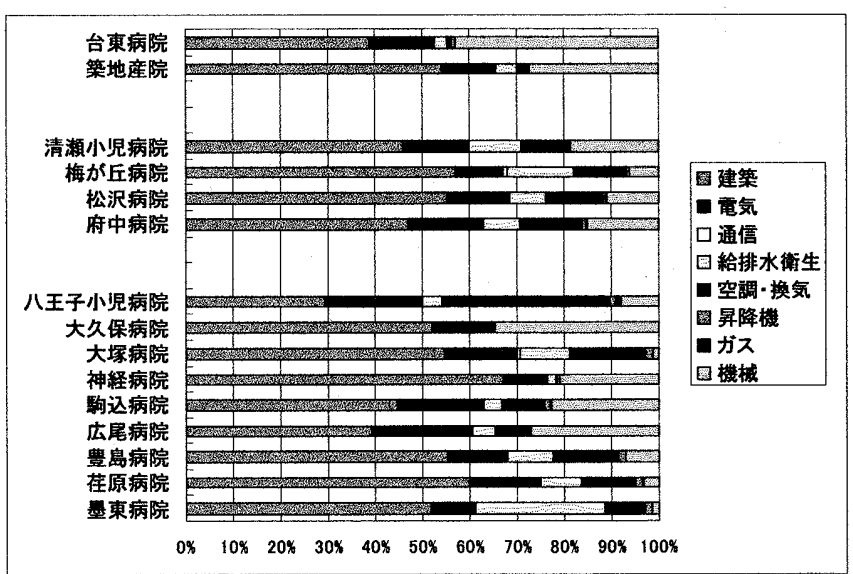

図 8 投資金額に対する各種工事の割合

全施設の投資金額の工種別割合をみると、全投資金額のなかで建築 工事を除いては、電気、空調・換気設備・給排水衛生設備工事も高い 割合を占め、建築とその他の設備工事の割合が、平均すると約 5 割に なり、病院建築では設備工事費の割合が高いことがわかる。

\section{2 工事種別でみた年次推移}

都立病院への投資状況の年次推移は、図 9 に示すとおりである。投 資金額の増加 ${ }^{5)}$ が、40 年代から顕著になり、特に、バブル期以降に は、改築工事が行われるなど、一層、投資金額が大きくなっているこ とがわかる。

こうしたことの理由としては、昭和 30 年代から始まった病院相互 の統合や、新しい医療科目の設置に基づく工事、社会環境の変化に応 じた全館の空調設備工事や、患者への快適空間確保のための病室の個 室化、2 人部屋への改修、増築などに加えて、40 年代からは、病院の 不燃化が急速に求められ、鉄筋コンクリート造への改築なども頻繁に 行われてきていることが挙げられる。

そのため、病院への投資金額の増加も 40 年代から顕著になり、バ ブル期には、建築で 30 万円 $/ \mathrm{m}^{2}$ を超えて、 $\mathrm{m}^{2}$ 当りの投資金額が最大 となっている。しかしながら、平成 11 年以降については、財政の緊 縮から投資が抑制されてきている。 


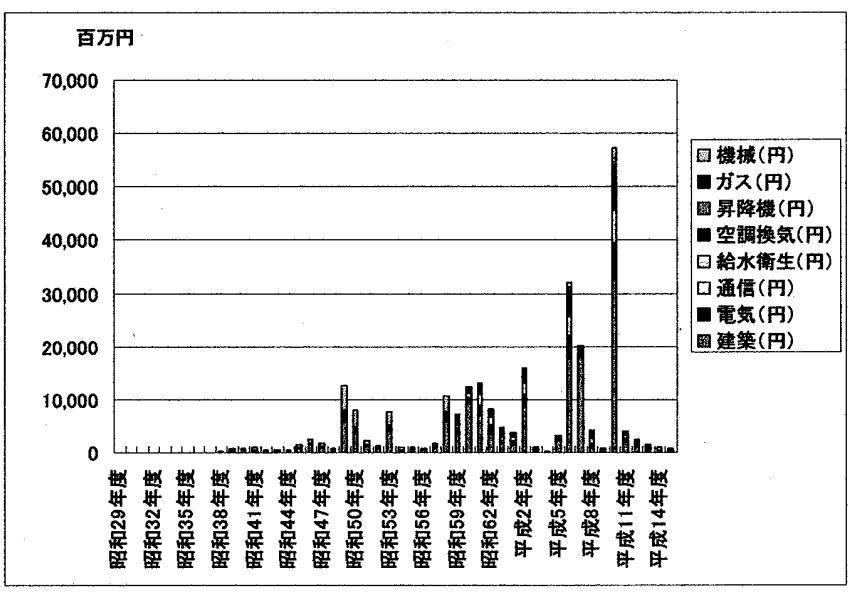

図 9 工種別投資金額の総計推移

\section{5. 都立病院の改修·改築工事期間}

\section{1 駒込病院での改修事例分析}

病院施設の新策および改勧から、次の改勧・改修までの工事期間の 間隔に着目して、都立 13 病院各々についての改修・改筑工事におけ る投資金額の推移が捉えやすい図を作成した。

図 10 は、駒込病院のものであり、昭和 49 年の新築工事から次の大 規模な改修工事までの間隔は 11 年であることがわかる。

また、小規模の改修工事が、1〜3 年の周期で頻繁に行われているこ とや、近年、耐震補強工事や昇降機工事などが行われていることがわ かる。

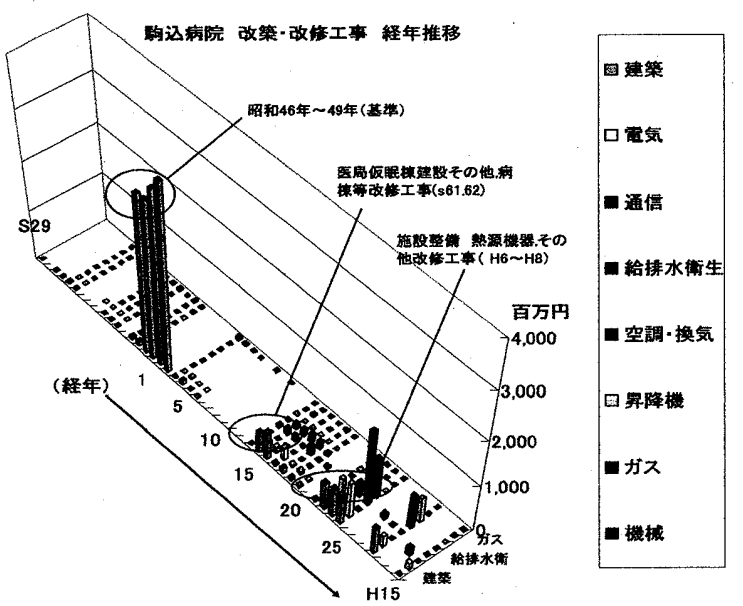

図 10 駒込病院の改修工事投資金額推移

\section{2 大規模な改修工事までの間隔}

都立病院各々の新築、及び改築から大規模な改修工事までの間隔を、 図 11 に示している。なお、図 11 で記されている単独棟型病院・キャ ンパス型病院の区分は、それぞれ現在の状態で捉えている。

単独棟型：「敷地がキャンパス型に比べると狭く、基本的な病院機 能を主軸となる 1 棟で行う病院」、キャンパス型 :「敷地が広く、病院 の総合的な機能を複数棟で分担している病院」と定義し、これを基に 分類している。都立 13 病院の大規模な改修までの周期間隔は、単独 棟型とキャンパス型で異なり、単独棟型は平均 7.11 年である。
キャンパス型は平均 3.72 年の間隔であり、一つの棟を見れば、単 独棟型より間隔が長いものもあることが推察できる。全体としては、 比較的短い間隔で、どこかの棟で大規模な改修を行っていることがわ かる。

なお、この場合の単独棟型の間隔は、新築当時からの単独棟型は元 より、キャンパス型から単独棟型に改筑されたものについては、単独 棟型に改築された以降における大規模な改修までの間隔を対象に平 均を求めている。

さらに、小規模な改修工事に関しては、キャンパス型、単独棟型を 問わず、各病院とも同様に、1 3 年間隔で、いろいろな改修工事がな されていることがわかった。(図 12)

大規模な改修工事の間は、設備の小規模な改修工事が頻繁に行われ ている。このような小規模な改修工事によって、建物の機能を維持、 更新していると考えられる。

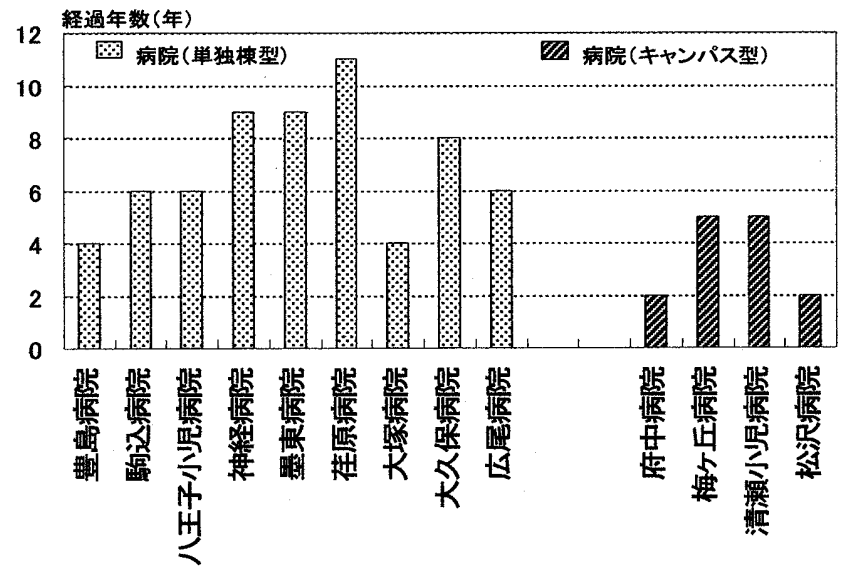

図 11 都立 13 病院の改修工事間隔

画方

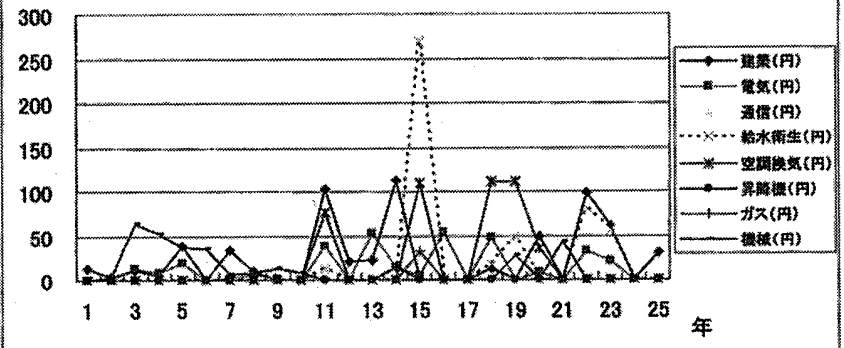

図 12 清瀬小児病院の改修投資金額の推移

\section{3 改築工事までの間隔}

改修工事と同様に、病棟等での改築工事の間隔を示したものが、図 13 である。

都立病院の改策間隔は、単独棟型病院で、平均 27.4 年であった。 ここでは、単独棟型 9 病院のうち豊島病院は、前の改築から大規模な 改築（平成 10 年）までの間隔であり、荏原病院、墨東病院も同様な 間隔である。この 3 病院の改築から改築までの間隔は 31.3 年である。 なお、大久保病院については、資料が不足しているため、大規模な増 築から次の改築までの間隔としている。 
他の 5 病院は、新筑や前の改築から平成 15 年までの期間としてい る。しかし、これらの 5 病院は、平成 18 年である現在も改筮が行わ れず、継続して使用されている状況にある。

こうしたことを囦まえると、実際の改築間隔は、平均 27.4 年より も大きい值と考えるのが妥当であり、それも 30 年以上と考えること に基本的に無理はないといえる。

また、キャンパス型病院の改筑間隔は、平均 18 年になった。複数 棟が工事の対象であることを考えると、キャンパス型の改筑工事間隔 が、このように短くなるのは、当然であるといえる。

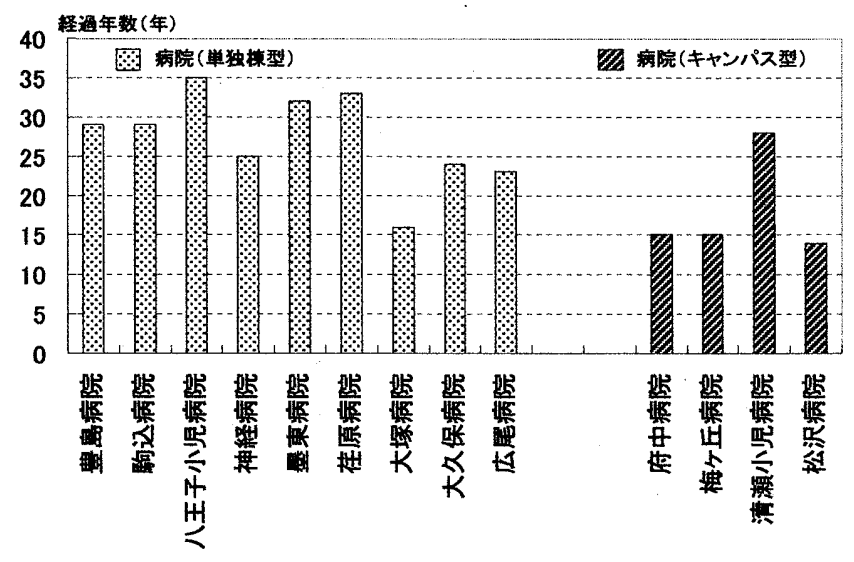

図 13 都立 13 病院の改築工事期間

\section{6. 改築後の改修等の特徵}

単独棟型病院のうち、広尾病院、駒込病院、神経病院、大塚病院は、 従来から比較的データが詳細にわかっており、それらを基に、4 病院 の改筑後の工種別費用状況を図示したものが、図 14〜17 である。改 築後直ぐに何らかの工事が行われていることがわかる。

この中には、工事が当初設計に基づき行われている途中で設計変更 の必要が生じても、設計変更として行うことができず、追加工事とし て行っているものがある。これは、現行の官公庁工事の契約制度にお いては、設計変更では行えない内容があることや、ある一定金額以上 の工事では、設計変更が認められないことによるためである。

また、改築後 5 年前後からは、薬剤科無菌室空調設備工事、心臟血 管撮影室の整備、病棟の内部改修、年降機地震管制設備、避難経路整 備などの工事が始まっている。これらは、病院特有の工事、あるいは 法的規制から生じた工事である。

また、10 年を超える時期の工事には、放射性排水処理槽、MR I 室 增筑工事などの医療技術の進渉に伴う工事や、ナースコール改修工事 などの患者への対応工事がある。

しかしながら、広尾病院では、9 年目には、空調設備の一部改修が 必要となり、14 年目には、給湯・蒸気管などの大規模な設備改修工事 などが行われている。その翌年には、熱源機器の改修工事が行われて いる。

また、駒込病院は、建設工事が完了してすぐに、内部改修の追加工 事が行われ、14〜16 年目に掛けては、蓄電池、冷却塔などの取替え工 事が行われている。神経病院では、8 年目に、高温水配管取替えが始 まり、12 年からは給排水設備の改修が 2 度行われた後に、大規模に給 排水設備工事が行われている。大塚病院は、4,5 年目に、トイレや病 室の改修工事などが行われている。
これらの事例では、通常の事務所ビルとは異なって、設備の改修時 期が早くなっている。このことに法、病院が 24 時間に渡って使用さ れていることによる損耗が激しいことが大きく影響していると考え られる。工事の $\mathrm{m}^{2}$ 当りの費用も、10 年を超えた時期は、 2 万円前後で あるが、 20 年を超えると 3 万〜 5 万円までに達している。

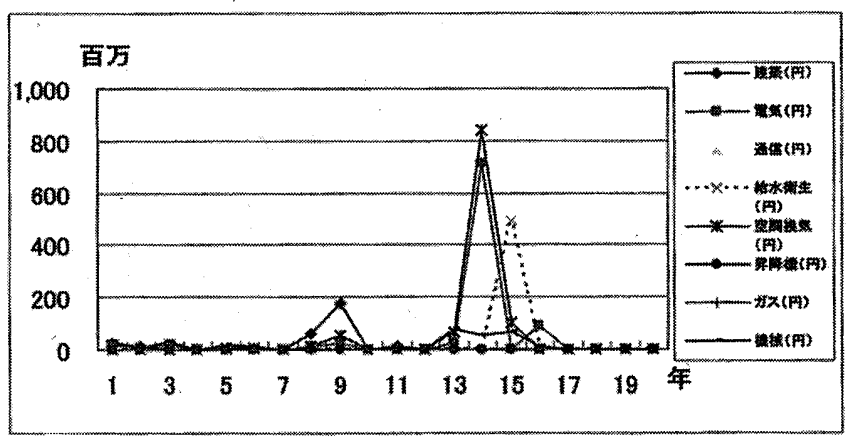

図 14 広尾病院における工種別投資金額の推移

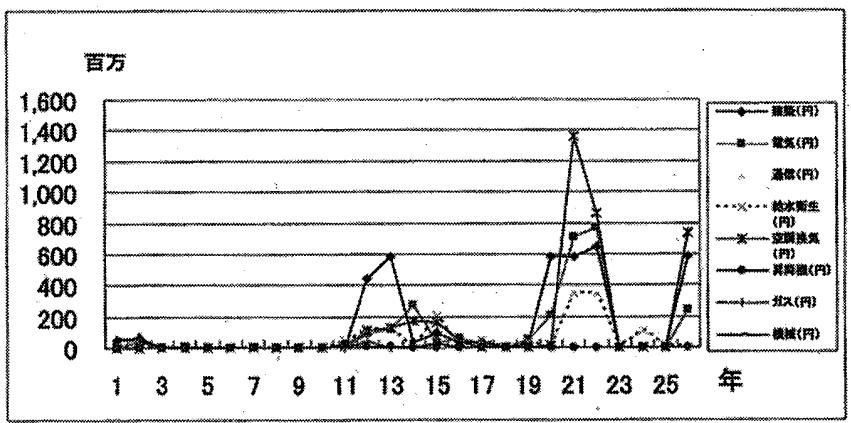

図 15 駒込病院における工種別投資金額の推移

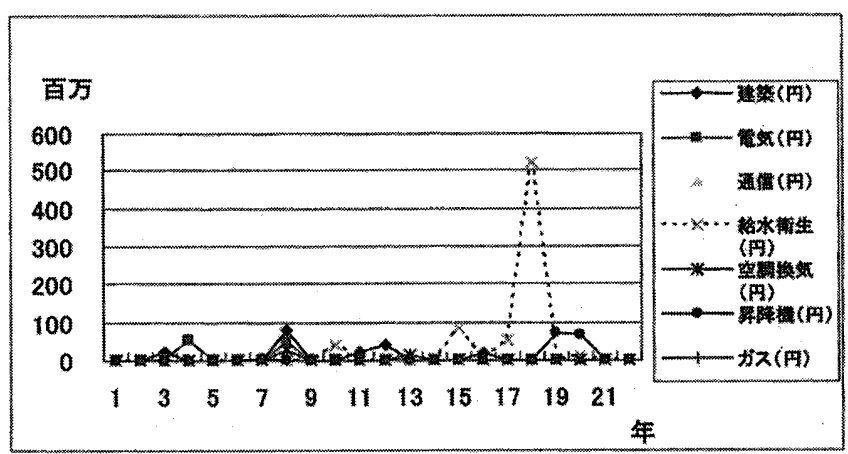

図 16 神経病院における工種別投資金額の推移

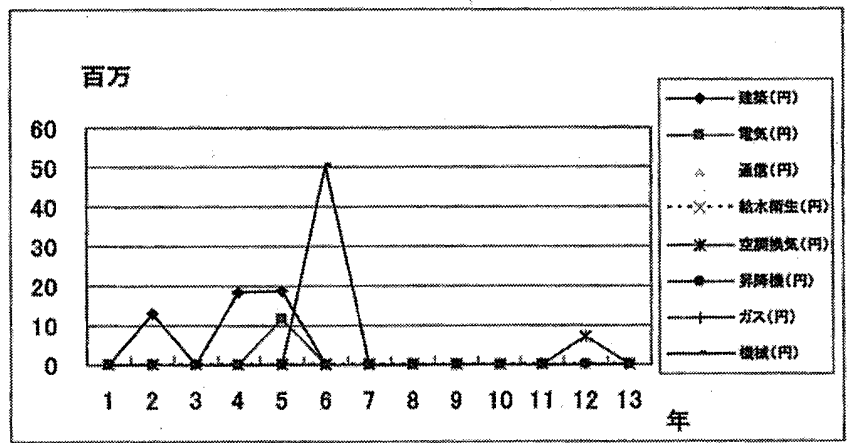

図 17 大塚病院における工種別投資金額の推移 
他の都立病院においても、同様に自閉症病棟の開設、腎不全センタ 一の新設、スモン等の神経難病の治療のための改修を行うなど、医療 に対する社会的要請に基づいた増築、改修も数多く見られる。

また、高龄社会での療養病床数の増加、病室での患者の快適性の確 保などの要因による改修等も行われている。

\section{7. まとめ}

医療サービスを提供する場である医療施設には、絶えず変化が要求 されている。医療技術の発展、患者の受療環境に対する社会的要請な ど、病院を取り巻く改修、增筑等の需要は限りなく多く、設備などの 工事も頻繁である。

本研究では、都立病院への投資金額の推移の分析から、新築または 改築から大規模な改修工事までの間隔は、単独棟型病院で、平均 7.11 年、キャンパス型病院で、平均 3.72 年であることを示した。

このことは、医療施設の特徴として、改修周期が短いということや、 投資金額における設備工事の比率が比較的高いということが一般的 に言われているが、これを裏付けるものである。

また、どの病院もほぼ毎年行っている小規模な改修工事の特徴を照 らし合わせて考えると、建物の維持のためというよりはむしろ、病院 機能を充実し、医療行為の発展に合わせて、より質の高い医療を提供 しょうとしている面が強いと考えられる。医療施設は、医療を支える 環境として、施設の機能を適切に維持することは元より、医療施設の 多様化、高度化への対応が求められているといえる。

また、医療施設の改築間隔の平均は、本研究の分析からでは、単独 棟型では、約 27.4 年であることを導いたが、実際は 30 年以上と考え られる。大規模な改修工事の周期も短く、小さな改修工事も頻繁に行 われていることは、患者を入院させたままの居ながら工事も十分にあ りうることを示している。

工事が頻繁に行われていることを考えると、工事期間を短くして、 設備の改修工事に素早い対応ができる高い階高や、転用し易い広い空 間構成などによって得られるフレキシビリティが、今後一層、重要に なるといえる。

また、一方では、医療施設の寿命を長くするのではなく、適切な医 療サービスを提供できる耐用年数を、例えば、30 年に限定した病院建 筑の計画も、現実的な選択肢の一つになるものと考えられる。

本研究の成果が、今後の医療施設における改築・改修等の施設運用 計画に活用いただけるものになれば幸いである。

\section{謝辞}

本研究を進めるにあたって、東京都財務局建築保全部の南部敏一氏、 東京都財務局および病院経営本部の方々に多大なご協力をいただき ました。ここに記して感謝いたします。

注

注 ${ }^{1)}$ 平成 17 年人口動態統計月報年計（概数）の概況 厚生労働省 2006 年 6 月 国内百歳以上高龄者数等訂正関係資料について 厚生労働省 2005 年 9 月 日本人の平均余命平成 17 年簡易生命表 厚生労働省 2006 年 7 月

注 2)「医療施設調查」(厚生労働省)

注 3) 「医療施設（動態）調查・病院報告の概況」厚生労働省 H.P

注 4) 大久保病院は、平成 16 年 4 月に、萑原病院は平成 18 年 4 月に、それぞれ 東京都から (財) 東京都保健医療公社に移管しているが、分析デー夕を活用
できるため東京都の病院数に入れてある。

注 ${ }^{5}$ 新築工事などの投資金額が複数年度に渡っているもののうち、年度ごとに 計上されているものは、そのまま分析できる。しかしながら、複数年度に渡 つている累計の総工事金額が、例えば、工事開始年度に一括計上されている 場合がある。この場合、各年の実際の投資金額と違った投資金額とならざる を得ない。

参考文献

1）山本康友、吉田倬郎 都立病院における改修工事費等の推移と分析 日本 建築学会大会学術講演梗概集 (北海道) pp. 8052-8053 2004.9

2）山本康友、吉田倬郎、山下光博 都立病院に膡ける投資金額の推移と分析 第 22 回建築生産シンポジウム論文集 pp. 252-258 2006.7

3）下島光徳、福田綾乃 建築市場に関する研究 工学院大学建築学科吉田研 究室卒業論文 2003.3

4）山下光博、吉田倬郎、山本康友 都立病院に圈ける投資金額の推移と改筑 改修工事費の特徴の分析 工学院大学研究報告第 101 号 2006.10

5）「東京都病院経営本部 H. P. (2006.9.1) 事業概要、都立病院改革会議報告書」 http://www. byouin. metro. tokyo.jp/index. html を参照してください。

6）「財団法人東京都医療保健公社 H.P. (2006.9.1) 大久保病院、荏原病院概要」 http://www6. ocn. ne.jp/ iryo-hp/を参照してください。

7）「厚生労働省 H.P (2006.9.1) 2004 医療施設（動態）調查・病院報告の概況」 http://www. mhlw. go. jp/toukei/saikin/hw/iryosd/04/dl/data. pdf を参照 してください。

8）松沢病院百年のあゆみと現況 東京都立松沢病院 1979 年 11 月

9）衛生局 50 年史 東京都 平成 8 年 12 月

10）果京都の医療施設 一平成 16 年医療施設 (動態) 娚查・病院報告結果報告 集一 東京都福祉保健局 平成 18 年 4 月

11）東京都病院改革マスタープランー21 世紀の新しい都立病院の創造一 東 京都 平成 13 年 12 月

12）都立病院改革会議報告集 都立病院改革会議 平成 13 年 7 月

13）都立病院の患者権利章典一東京都立病院倫理委員会報告一 東京都衛生局 平成 13 年 7 月

14）建築物ストックの推計 建築物ストック研究会 2002 年 11 月

15）都立病院施設概要 東京都病院経営本部財務課施設計画担当 2003 年 1 月

16）山本康友、吉田倬郎 日本国内の公共建築のストック量とその地域的な特 徵に関する調查研究 : 日本建築学会計画系論文集 N0.587 pp143-pp148 2005 年 1 月

17）野城智也ら 東京都中央区における事務所建築の寿命実態 日本建築学会 計画系論文集第 413 号 1997 年

（2006年 9 月 10 日原稿受理，2007年 1 月 5 日採用決定 